\title{
A Novel Type of Nicotinic Receptor in the Rat Central Nervous System Characterized by Patch-Clamp Techniques
}

\author{
Christophe Mulle and Jean-Pierre Changeux \\ URA CNRS 0210 "Neurobiologie Moléculaire," Département des Biotechnologies, Institut Pasteur, 75724 Paris Cedex 15, \\ France
}

\begin{abstract}
We present a functional characterization of a neuronal nicotinic receptor in the CNS using patch-clamp techniques and a preparation of acutely isolated neurons from the medial habenular nucleus of 10 - to 20 -d-old rats. The salient pharmacological and electrophysiological properties of this nicotinic response are (1) its association with a channel that is relatively nonselective for cations and has a unitary conductance of $26.2 \pm 5 \mathrm{pS}$ at room temperature; (2) its insensitivity to $\alpha$-bungarotoxin and to neuronal bungarotoxin; (3) its activation by the ganglionic nicotinic agonists nicotine, 1,1-dimethyl-4-phenylpiperazinium and cytisine and its blocking by several nicotinic antagonists, mecamylamine, hexamethonium, $d$-tubocurarine, and dihydro- $\beta$-erythroidine. The combination of these properties has not been reported for any other known type of nicotinic receptor.
\end{abstract}

The presence of functional nicotinic acetylcholine receptors (AChR) has been demonstrated in various regions of the vertebrate CNS by electrophysiological techniques. These regions include cat spinal cord (Curtis and Ryall, 1966; Duggan et al., 1976), brain stem (Bradley and Dray, 1972), interpeduncular nucleus (Brown et al., 1984), substantia nigra (Clarke et al., 1985a), hypothalamus (Miller et al., 1987), locus coeruleus (Egan and North, 1986), cerebellum (Garza et al., 1987), medial habenula (McCormick and Prince, 1987a), lateral geniculate nucleus (McCormick and Prince, 1987b), and frontal neocortex (Vidal and Changeux, 1989). Although the neuronal nicotinic receptors that mediate synaptic transmission through ganglia of the autonomic nervous system have been well studied, no detailed direct electrophysiological characterization of CNS nicotinic AChR has, to our knowledge, been performed in situ. Yet, neuronal nicotinic AChRs have been characterized in primary cultures of retinal ganglion cells (Lipton et al., 1987) and, in a preliminary fashion, of hippocampal cells (Aracava et al., 1987).

Recent studies of cloned nucleic acid sequences have demonstrated the existence of a family of genes that encode functional nicotinic receptors found in muscle and in nerve cells (for review, see Lindstrom et al., 1987; see also Deneris et al., 1988a,

\footnotetext{
Received Apr. 28, 1989; revised June 30, 1989; accepted July 6, 1989

This work was supported by grants from the Muscular Dystrophy Association of America, the College de France, the Ministère de la Recherche, CNRS, INSERM (contract no. 872 004) and the DRET (contract no. 87/211). We wish to thank Catherine Vidal and Pierre Benoit for helpful discussion.

Correspondence should be addressed to Christophe Mulle, Laboratoire de Neurobiologie Moléculaire, Département des Biotechnologies, Institut Pasteur, 25 rue du Dr. Roux, 75724 Paris Cedex 15, France.

Copyright (c) 1990 Society for Neuroscience $0270-6474 / 90 / 010169-07 \$ 02.00 / 0$
}

b; Nef et al., 1988; Wada et al., 1988). The question thus arises as to how many neuronal receptors can be distinguished in terms of function in the CNS?

The localization of nicotinic AChRs in the vertebrate CNS has benefited from several different techniques such as autoradiography with radiolabeled cholinergic ligands like $\mathrm{ACh}$, nicotine, and dihydro- $\beta$-erythroidine (Williams and Robinson, 1984; Clarke et al., 1985; London et al., 1985), immunocytochemistry with monoclonal antibodies (Deutch et al., 1987; Swanson et al., 1987), in situ hybridization of putative mRNAs (Goldman et al., 1986, 1987; Deneris et al., 1988a, b; Wada et al., 1988), and local cerebral glucose utilization (London et al., 1988).

A direct correlation exists between rat brain regions which exhibit high-affinity binding for ${ }^{3} \mathrm{H}-\mathrm{ACh}$ and ${ }^{3} \mathrm{H}$-nicotine (Clarke et al., 1985b) and those which react with ${ }^{125} \mathrm{I}-\mathrm{mAb} 270$ (Swanson et al., 1987) or mAb 35.76 (Deutch et al., 1987). Among these regions, the medial habenular nucleus (MHb) exhibits prominent reactivity and is the locus of substantial increase in local glucose utilization in response to peripheral nicotine application (London et al., 1988). Moreover, in situ hybridization with various RNA probes reveals that several different genes of the nicotinic AChR family are expressed in the MHb (Boulter et al., 1986; Goldman et al., 1986, 1987; Deneris et al., 1988a, b; Wada et al., 1988).

The MHb is a cytoarchitectonically homogeneous group of densely packed small neurons (diametcr, 8-20 $\mu \mathrm{m}$ ) which lics in the medial part of the dorsal thalamus. It receives most of its afferents from the posterior septal region (Gottesfeld and Jacobowitz, 1979; Contestabile and Villani, 1983) and gives rise to a large axonal projection through the fasciculus retroflexus to the interpeduncular nucleus and the median raphe (Herkenham and Nauta, 1979). Recent electrophysiological evidence using extra- and intracellular recordings in a slice preparation confirmed the presence of a nicotinic response in cells from the guinea pig MHb (McCormick and Prince, 1987a).

In the present study, we characterize the electrophysiological and pharmacological properties of a nicotinic receptor present on $\mathrm{MHb}$ neurons using patch-clamp techniques and a preparation of acutely isolated neurons.

\section{Materials and Methods}

Isolation of neurons. The procedure is based upon the method of Kay and Wong (1986). The brains from Sprague-Dawley rats were rapidly removed and placed in cold $\left(\approx 5^{\circ} \mathrm{C}\right)$ PIPES saline (in mM: $120 \mathrm{NaCl}, 5$ $\mathrm{KCl}, 1 \mathrm{CaCl}_{2}, 1 \mathrm{MgCl}_{2}, 25$ D-glucose, 20 PIPES-NaOH; pH 7.0, preequilibrated with $100 \% \mathrm{O}_{2}$ ). Both habenular nuclei (consisting of lateral plus $\mathrm{MHb}$ ) were dissected, cut into halves, and incubated in $10 \mathrm{ml}$ PIPES saline containing papain 50 units (Sigma). The tissue was stirred 

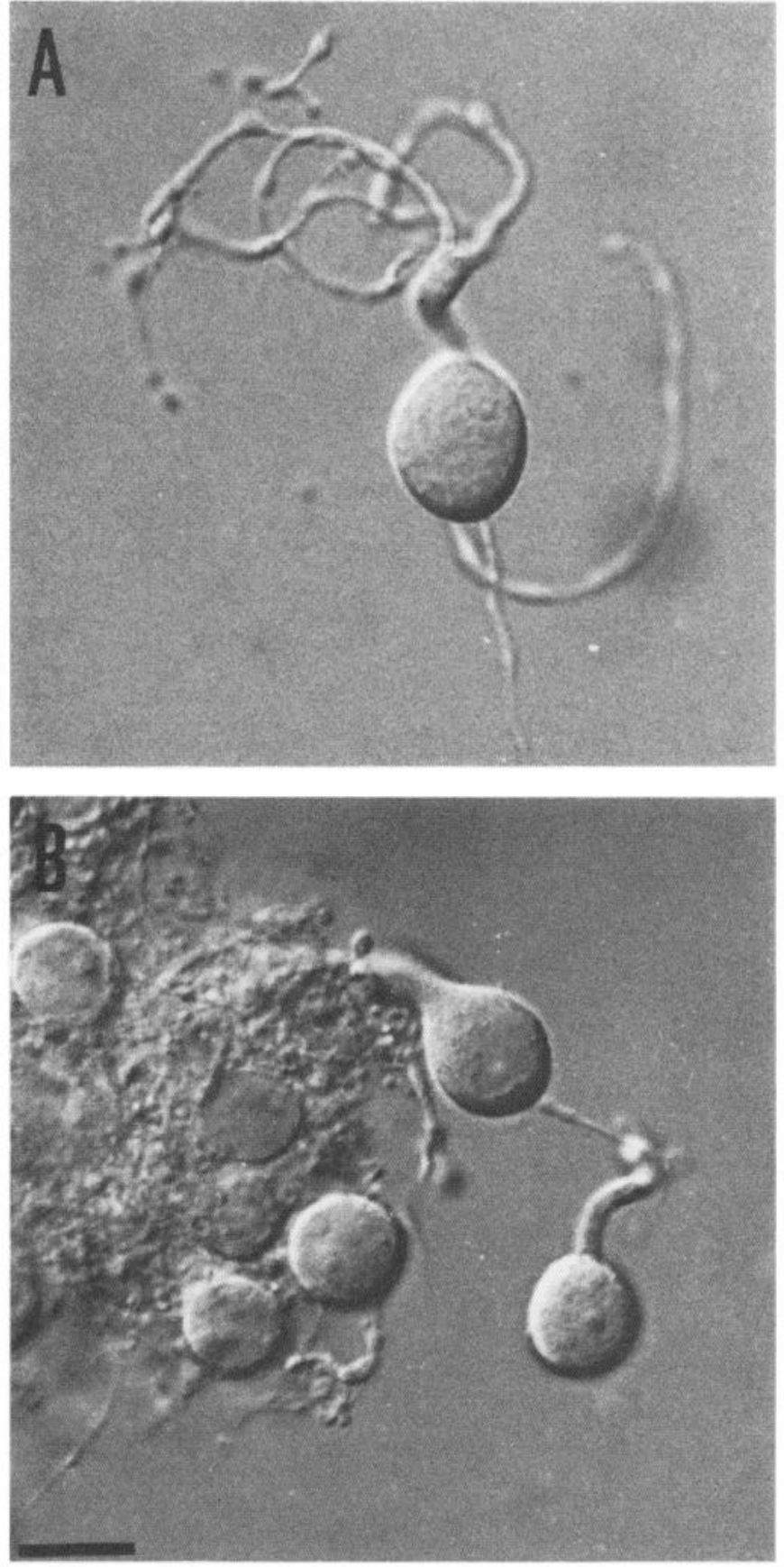

Figure 1. Small cells freshly dissociated from the habenular nucleus of a 17-d-old rat. Pictures were obtained using Nomarski optics. Scale bar, $8 \mu \mathrm{m}$.

gently under pure $\mathrm{O}_{2}$ atmosphere at $37^{\circ} \mathrm{C}$ for $1 \mathrm{hr}$. The pieces of tissue were then rinsed several times in fresh PIPES saline containing $1 \mathrm{mg}$ / $\mathrm{ml}$ BSA, at room temperature. Cells were isolated when needed by pipette trituration in Dulbecco's modified Eagle's medium with $20 \mathrm{~mm}$ HEPES (GIBCO) and transferred to $35 \mathrm{~mm}$ petri dishes that had previously been coated with $2 \mu \mathrm{g} / \mathrm{ml}$ poly-l-ornithine (Sigma). The cells were allowed to settle for $10 \mathrm{~min}$ before beginning electrophysiological recordings.

Electrophysiology. The experiments were performed at room temperature. The cells were continuously superfused in a solution containing $150 \mathrm{~mm} \mathrm{NaCl}, 5 \mathrm{~mm} \mathrm{KCl}, 1 \mathrm{~mm} \mathrm{CaCl}_{2}, 10 \mathrm{~mm}$ HEPES- $\mathrm{NaOH}$, and 10 mм D-glucose (pH 7.2). All drugs, unless stated otherwise, were applied externally by means of a fast microperfusion system. The perfusion tube was positioned $100-200 \mu \mathrm{m}$ from the cell so that $\mathrm{ACh}$-activated currents
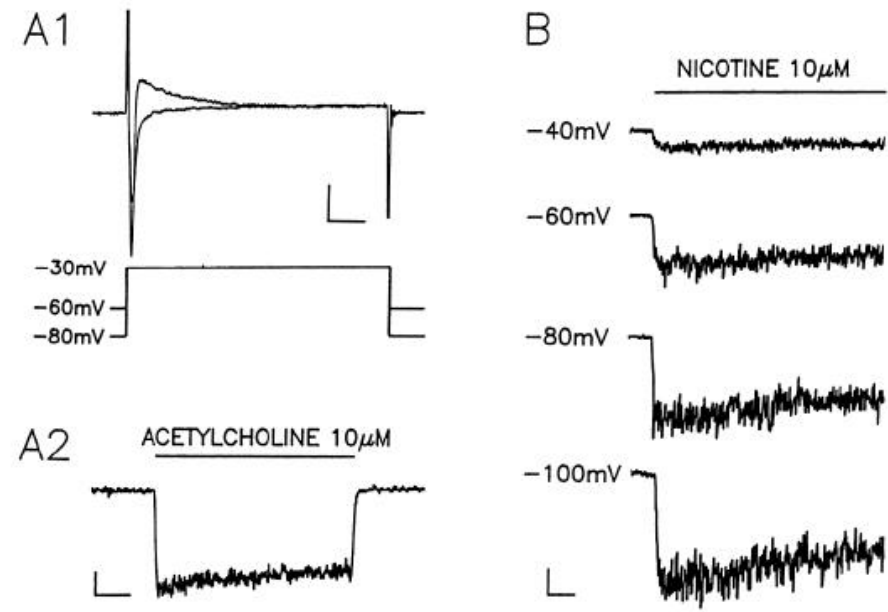

Figure 2. A, Whole-cell recordings from a small neuron freshly dissociated from the habenular nucleus. $A 1$, Voltage-dependent currents activated by depolarizing steps. A transient outward current, resembling the type- $\mathrm{A} \mathrm{K}^{+}$current, is activated when the holding potential is held at $-80 \mathrm{mV}$ but not at $-60 \mathrm{mV}$. $A 2$, Inward current activated by $\mathrm{ACh}$ in the same neuron; holding potential: $-60 \mathrm{mV}$; calibration: $500 \mathrm{pA}$, $20 \mathrm{msec}$. $B$, Amplitude of inward currents activated by nicotine increases with hyperpolarization with an extrapolated reversal potential around $-20 \mathrm{mV}$; calibration: $100 \mathrm{pA}, 2 \mathrm{sec}$.

could reach a maximum in less than $0.5 \mathrm{sec}$. This perfusion system allowed a change in the solution contained in the perfusion pipettes in less than $5 \mathrm{sec}$, as visualized with dyes. Macroscopic currents were recorded using the whole-cell variation of the patch-clamp technique (Hamill et al., 1981). The solution in the patch pipette contained, unless stated otherwise, $140 \mathrm{~mm} \mathrm{KCl}, 4 \mathrm{~mm} \mathrm{NaCl}, 2 \mathrm{~mm} \mathrm{MgCl}, 1 \mathrm{~mm} \mathrm{CaCl}_{2}$, $10 \mathrm{~mm}$ HEPES-KOH, $11 \mathrm{~mm}$ EGTA, and $100 \mu \mathrm{M}$ leupeptin (Sigma) (a $\mathrm{Ca}^{2+}$-activated neutral protease inhibitor). Recordings were made from phase-bright cells that retained visible neuritic processes. Two types of cells could be distinguished with respect to their size. The large bipolaror multipolar-shaped cells with thick axons likely represented cells from the lateral habenula or from surrounding brain regions. Response to ACh or nicotine was never observed in these cells. The small cells probably belonged to the MHb (see Results).

Preliminary experiments were performed at the adult stage. Large responses to $\mathrm{ACh}$ and nicotine were recorded in only 3 out of 40 small neurons. The small number was not suitable for an extensive study of these cholinergic responses. Experiments reported in this paper are from 10 - to 20 -d-old animals where $70 \%$ of the cells were responsive to nicotine.

As a probable consequence of the type of preparation and/or of the small size of neurons from the MHb, the duration of the recording sessions rarely exceeded $10 \mathrm{~min}$. Single-channel recordings were obtained in the outside-out configuration in order to ascertain the nicotinic nature of the channels we recorded. The currents were monitored with an Axopatch $1 \mathrm{C}$ (Axon Inst., Inc.) filtered at $2 \mathrm{kHz}$ and analyzed on an IBM AT with the program PClamp of Axon Instruments (Inc.). All values are given as means \pm SD.

All compounds, unless mentioned, were obtained from Sigma. Dihydro- $\beta$-erythroidine was donated by Merck, Sharp and Dohme. Neuronal bungarotoxin was purified by A. Menez (CEA, Saclay, France) according to the method of Loring et al. (1984). We confirmed its ability to block ACh response on chick ciliary ganglion cells in culture (total block occurs at $0.2 \mu \mathrm{M}$ when applied in the bathing medium).

\section{Results}

Morphology and electrophysiological characteristics of $\mathrm{MHb}$ cells

MHb cells were acutely dissociated following the procedure of Kay and Wong (1986) and could thus be identified on the basis of their morphology. Most of them consisted of small (diameter, $<10 \mu \mathrm{m}$ ) round or slightly elongated neurons (Fig. 1). These 

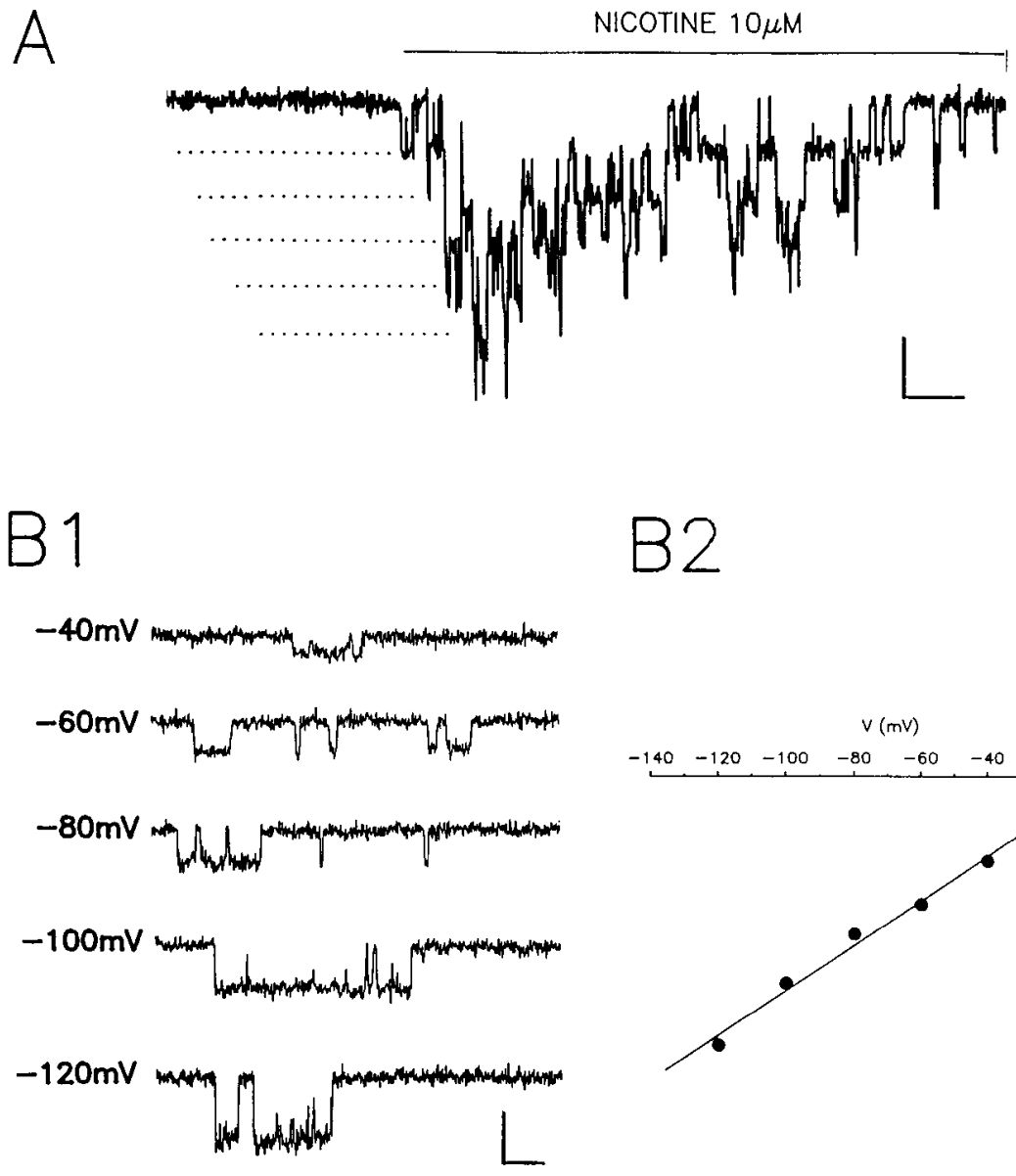

Figure 3. Single-channel currents
evoked by nicotine recorded in the out-
side-out configuration. $A$, In control
conditions, no channel openings are ob-
served. Addition of nicotine results in
the simultaneous opening of up to 6
channels. All channels display the same
unitary current, as indicated by the dot-
ted lines. Membrane potential was held
at $-80 \mathrm{mV}$; calibration: $2 \mathrm{pA}, 200 \mathrm{msec}$.
$B: B 1$, In another patch, current records
at various potentials in the presence of
$10 \mu \mathrm{M}$ nicotine. Calibration: $2 \mathrm{pA}, 20$
msec. $B 2$, Corresponding current-vol-
tage relationship. Linear regression gives
an elementary slope conductance of 25
pS and a reversal potential of $-6 \mathrm{mV}$.

neurons were in general bipolar and preserved at one end a thick, often ramified, dendritic shaft (see for instance Fig. 1A); at the other end, a thin process, presumably an axon, ran for several tens of microns without any ramification. In the little pieces of tissuc rcmaining undissociated (Fig. $1 B$ ), similar small perikarya appeared densely packed. These features are in agreement with former morphological studies of the MHb (Ramón y Cajal, 1911; Tokunaga and Otani, 1978).

These cells had a resting potential around $-55 \mathrm{mV}$ immediately after breaching the cell and a capacitance ranging between 4 and $6 \mathrm{pF}$. All cells displayed the typical transient sodium current and were thus identified as neurons. Large outward currents were also activated by depolarizing pulses. A characteristic of these cells was the presence of a $\mathrm{K}^{+}$current [abolished when replacing $\mathrm{K}^{+}$by $\mathrm{Cs}^{+}$in the presence of $20 \mathrm{~mm}$ tetraethylammonium (TEA)] which resembled an A-current (Gustafsson et al., 1982): this fast-inactivating transient outward current could be activated by depolarizing pulses when the resting membrane potential was held below $-80 \mathrm{mV}$ but not when it was held above $-60 \mathrm{mV}$ (Fig. 2AI).

\section{Electrophysiological characteristics of the nicotinic response}

In $70 \%(158 / 227)$ of such small neurons, $\mathrm{ACh}$ and/or nicotine evoked without any delay $(<100 \mathrm{msec})$ a rapidly activating inward current accompanied with an increase in noise (Fig. 2A2). At a holding potential of $-60 \mathrm{mV}$, the amplitude of the current activated by $10 \mu \mathrm{M}$ nicotine covered a broad range of values, ranging from 50 to $900 \mathrm{pA}$ (mean $\pm \mathrm{SD}=243 \pm 231$
$\mathrm{pA}, n=110$ ). The amplitude of the response did not vary with the age of the animal, at least between 10 and $20 \mathrm{~d}$.

The amplitude of the response often declined in the first minutes of recording with little if any reversibility even when agonist applications were short ( $<10$ sec) and sparsed (one pulse every $2 \mathrm{~min}$ ). This decline was either due to a slow desensitization process (which would imply a very slow recovery rate) or to a wash-out phenomenon such as that described for GABA-A currents in hippocampal neurons (Stelzer et al., 1988). The rate of desensitization was fairly low (with a $t_{1 / 2}$ greater than $10 \mathrm{sec}$ ) for $10 \mu \mathrm{M}$ nicotine, although this concentration gave a robust response. This concentration of nicotine was thus selected, unless mentioned, to characterize the relevant receptor.

The inward current activated by nicotine increased with voltage (Fig. 2B). Reversing the current at positive potentials was complicated by the presence of large $\mathrm{K}^{+}$currents. Replacing $\mathrm{K}^{+}$ by $\mathrm{Cs}^{+}$did not suffice to eliminate outward currents at positive potentials. Yet, these currents were totally suppressed by replacing $\mathrm{K}^{+}$by $\mathrm{Cs}^{+}$and adding TEA (20 mM) in the intracellular medium. However, under these conditions, no outward current was observed in response to nicotine at positive potentials. This was possibly a consequence of a response block by TEA, which is known to act, at this concentration, as a rather nonspecific blocker of nicotinic receptors. Current-voltage relationships obtained with whole-cell currents gave an estimate reversal potential ranging between -20 and $0 \mathrm{mV}$, compatible either with a nonselective cationic current or with anionic current. Substitution for $\mathrm{Cl}$ in the pipette with gluconate did not affect the 

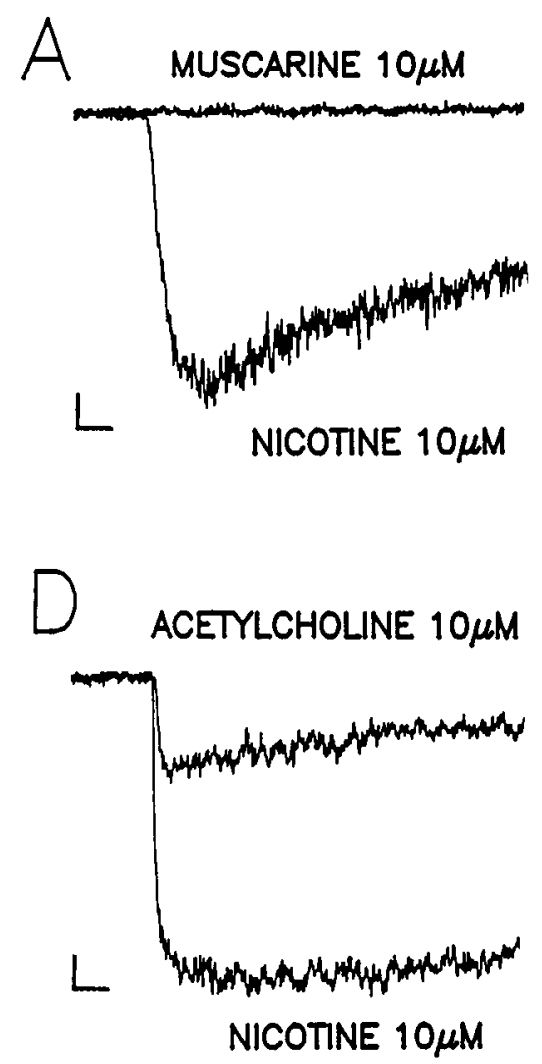
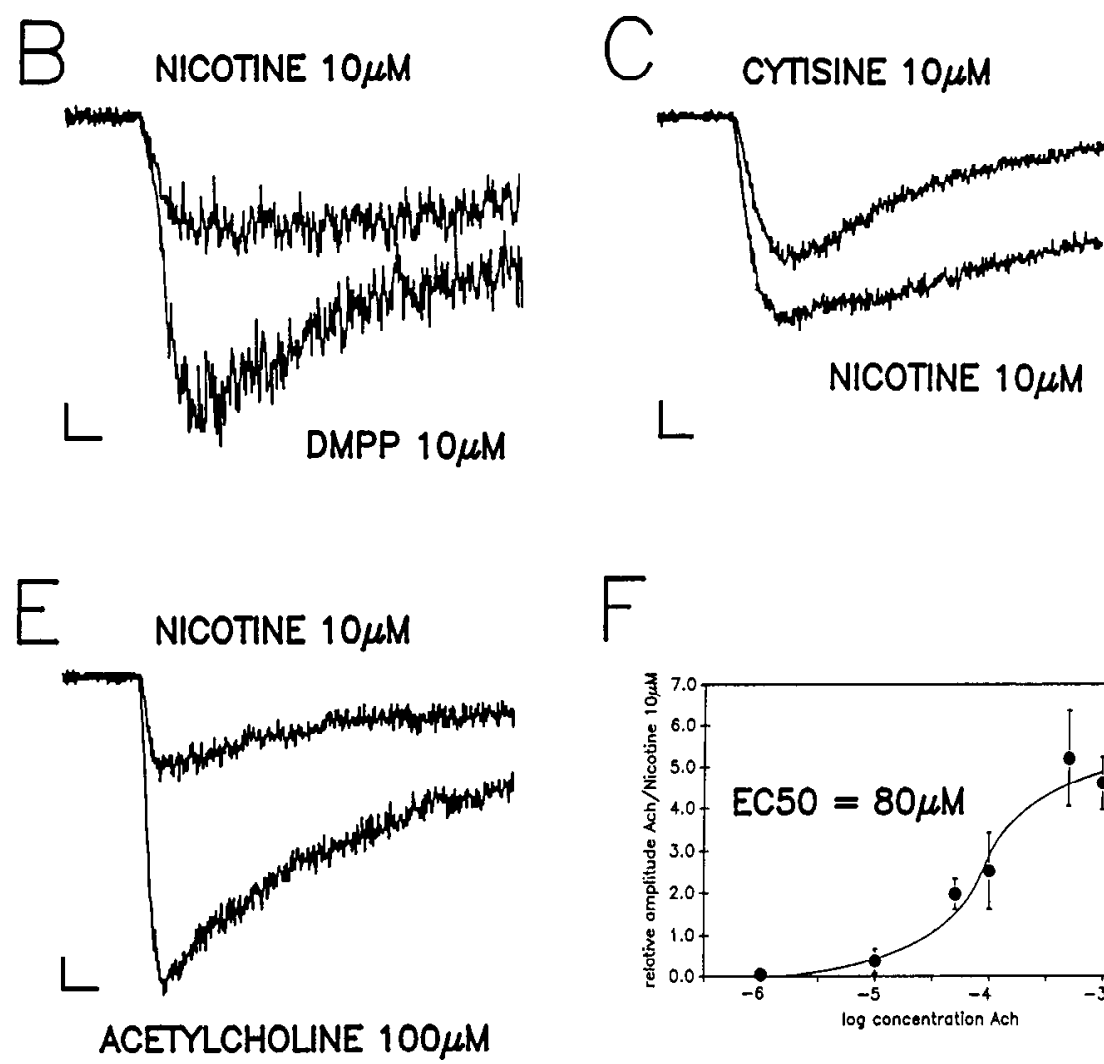
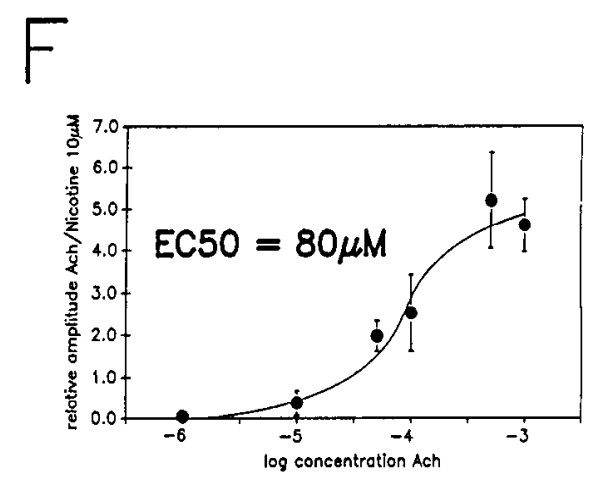

Figure 4. Response of $\mathrm{MHb}$ cells to various cholinergic agonists, compared with the response to $10 \mu \mathrm{M}$ nicotine. Each pair of recordings is from a different cell. The membrane potential was held at $-60 \mathrm{mV}$. Calibration: $50 \mathrm{pA}, 1 \sec$ for $A, C, D$, and $E ; 25 \mathrm{pA}, 1 \mathrm{sec}$ for $B$. In $F$, dose-response curve for ACh was obtained by comparing the peak amplitude of currents evoked by $10 \mu \mathrm{M}$ nicotine to that evoked by various concentrations of ACh. Each point represents the mean $( \pm S D)$ of at least 3 different measurements in 3 different cells.

reversal potential ( $n=3$, not illustrated). We also replaced the standard $150 \mathrm{~mm} \mathrm{NaCl}$ external medium with $15 \mathrm{~mm} \mathrm{NaCl}$ plus mannitol $270 \mathrm{~mm}$ (in order to maintain osmolarity at a normal level). Under these conditions, the response to nicotine measured at $-60 \mathrm{mV}$ decreased by about $80 \%(n=3)$. These results, together with single-channel measurements of reversal potential, suggest that the current activated by $\mathrm{ACh}$ in $\mathrm{MHb}$ neurons is relatively nonselective for cations. It is similar in this respect to that observed for muscle and ganglionic nicotinic receptors.

\section{Single-channel recordings of nicotinic currents}

Outside-out recordings, performed at the somatic level of cells that displayed a typical inward current in response to $\mathrm{ACh}$ or nicotine, revealed the presence of single-channel currents activated by nicotine (Fig. 3). In the absence of agonist, these patches were totally inactive when potential was held below $-60 \mathrm{mV}$. Interestingly, with all patches recorded $(n=14)$, only a single class of current amplitude was detected, as illustrated in Figure $3 A$ in a patch where several channels were simultaneously active. Figurc $3 B I$ shows, for another patch and on a faster time scale, single channels recorded at different holding potentials. The corresponding current-voltage relationship for a single nicotineactivated channel is given in Figure $3 B 2$. The mean reversal potential was $-8.7 \pm 3.4 \mathrm{mV}(n=11)$ and the single-channel conductance obtained from the slope of the fitted line was 26.2 $\pm 5 \mathrm{pS}(n=11)$ at room temperature. Application of ACh (50 $\mu \mathrm{M})$ instead of nicotine-activated single channels with the same elementary conductance $(26.3 \pm 2.1 \mathrm{pS}, n=3)$. Furthermore, ACh did not activate any other type of channel at any holding potential tested.

\section{Pharmacological properties}

Agonists. The typical muscarinic agonist muscarine $(10 \mu \mathrm{M})$ was without effect (Fig. $4 A$ ), thus confirming the nicotinic nature of the $\mathrm{ACh}$ response in these cells. 1,1-Dimethyl-4-phenylpiperazinium (DMPP) (10 $\mu \mathrm{M}$ ) (Fig. $4 B$ ) and cytisine, $10 \mu \mathrm{M}$ (Fig. $4 C$ ), which activate ganglionic nicotinic receptors also behave as agonists with $\mathrm{MHb}$ cells. Because of the fragility of the dissociated habenular neurons and the short-lasting recording sessions, we obtained a dose-response curve for ACh only by comparing the amplitude of the currents activated by $\mathrm{ACh}$ at various concentrations to that activated by $10 \mu \mathrm{M}$ nicotine in the same cell (Fig. 4, $D, E$ ). Each point represents the mean of at least 3 values obtained in 3 different cells. Dose-response curve for ACh (Fig. $4 F$ ) gives an $\mathrm{EC}_{50}$ of about $80 \mu \mathrm{M}$ without any correction for desensitization. The relative potency of $\mathrm{ACh}$ (10 $\mu \mathrm{M})$ in the absence and presence of eserine (10 $\mu \mathrm{M})$, an acetylcholinesterase inhibitor, was unchanged $(n=3)$. The response progressively desensitized during prolonged application of the agonist, a process different from the rundown of nicotine-activated currents mentioned above, in that it was both reversible and dependent upon the concentration of agonist. The extent of desensitization varied from cell to cell, but its rate increased with increasing concentration of $\mathrm{ACh}$ (Fig. $4, D, E$ ); the half- 
A mecamylamine
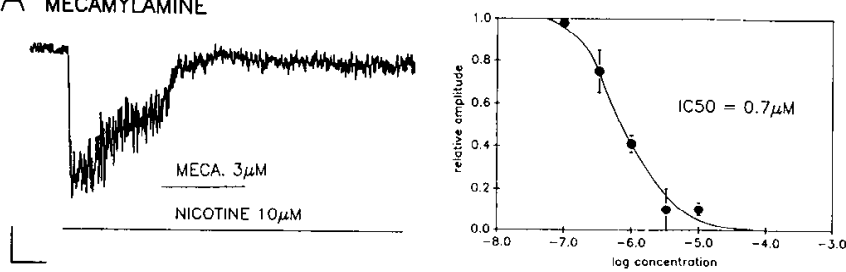

B HEXAMETHONIUM
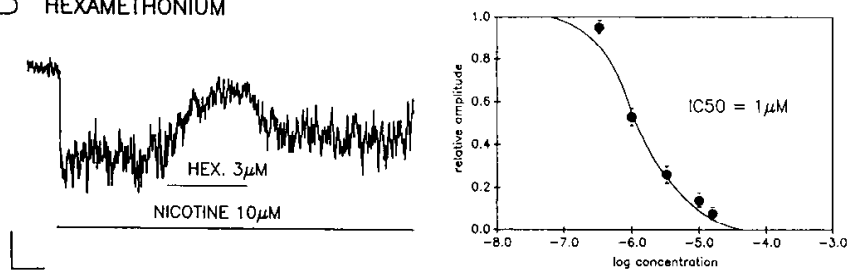

C D-TUBOCURARINE
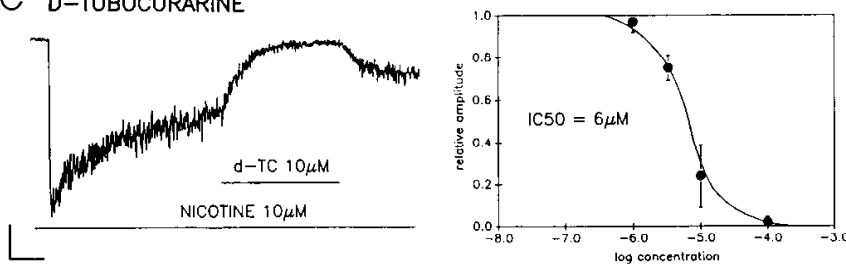

DIHYDROBERYTHROIDINE

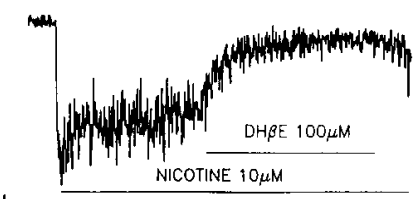

L

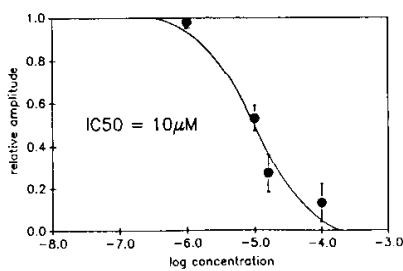

Figure 5. Effects of various nicotinic antagonists on the response to $10 \mu \mathrm{M}$ nicotine. The membrane potential was held at $-60 \mathrm{mV}$. Antagonists were applied through the same perfusion pipette as nicotine. Dose-response curves were obtained by comparing the amplitude of the current just before the application of antagonist to $5 \mathrm{sec}$ after its onset. Each point represents the mean $( \pm S D)$ of at least 3 different measurements made in 3 different cells. Calibration: $25 \mathrm{pA}, 5 \mathrm{sec}$ for $A, B$, and $D ; 50 \mathrm{pA}, 5 \mathrm{sec}$ for $C$.

decay times $\left(t_{1 / 2}\right)$ were as follows: $10 \mathrm{sec}$ at $10^{-6} \mathrm{M} \mathrm{ACh}(n=6)$, $6 \pm 2.8 \mathrm{sec}$ at $5 \times 10^{-5} \mathrm{M}$ ACh $(n=3), 3.9 \pm 1.7 \mathrm{sec}$ at $10^{-4}$ $\mathrm{M} \mathrm{ACh}(n=7)$, and $1.5 \pm 0.2 \mathrm{sec}$ at $10^{-3} \mathrm{M} \mathrm{ACh}(n=3)$.

Antagonists. Atropine, at a concentration $(1 \mu \mathrm{M})$ that totally inhibits muscarinic response in other systems, was without any effect. The nicotinic response was reversibly blocked by $d$-tubocurarine (Fig. $5 \mathrm{C})\left(\mathrm{IC}_{50}=6 \mu \mathrm{M}\right)$. Dihydro- $\beta$-erythroidine, which acts both at the neuromuscular junction and at ganglionic synapses, abolished the response to nicotine at somewhat higher concentrations $\left(\mathrm{IC}_{50}=10 \mu \mathrm{M}\right.$ ) (Fig. $5 D$ ). Among classical ganglionic antagonists, both hexamethomium and mecamylamine were found to be potent antagonists with $\mathrm{IC}_{50}$ values of 0.7 and $1 \mu \mathrm{M}$, respectively (Fig. 5, $A, B$ ). The effects of all the antagonists tested were reversible. However, in the case of mecamylamine, reversal was only obtained when nicotine was removed from the bath before a subsequent test application. No attempt was made to study the mode of action of these antagonists.

$\alpha$-Bungarotoxin, a potent nicotinic blocker in skeletal muscle,
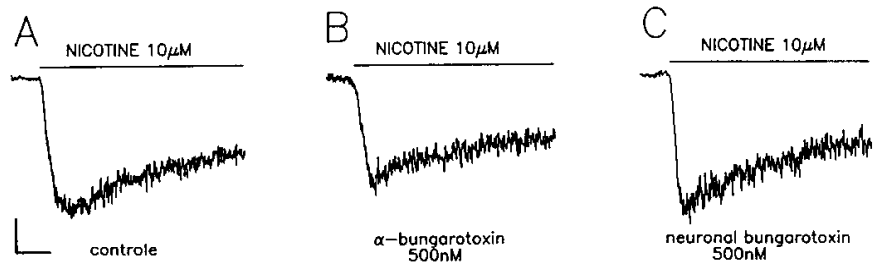

Figure 6. Inability of $\alpha$-bungarotoxin and neuronal bungarotoxin to block the nicotinic responsc recorded in MHb cells. The membrane potential was held at $-60 \mathrm{mV}$. In $A-C$, responses are obtained from 3 different representative cells. These cells were either bathed in normal saline $(A)$ or for more than $10 \mathrm{~min}$ in the presence of $\alpha$-bungarotoxin $(B)$ or neuronal bungarotoxin $(C)$.

either applied at the same time as nicotine with concentrations up to $2.5 \mu \mathrm{M}(n=6)$ or after preincubation with concentrations up to $5 \mu \mathrm{M}$ for more than $5 \mathrm{~min}(n=3)$, did not give significant inhibition (Fig. 6). Similarly, neuronal bungarotoxin (see Materials and Methods), which blocks neuronal nicotinic response in autonomic ganglia (Ravdin and Berg, 1979; Chiappinelli, 1983; Loring et al., 1984), added to the bath at concentrations of $0.2-$ $2 \mu \mathrm{M}$ for $10 \mathrm{~min}$ or more before recording, did not affect the amplitude of the nicotine evoked current $(A=280 \perp 130 \mathrm{pA}$, $n=6$ ) (Fig. 6).

\section{Discussion}

In this study, we present a detailed pharmacological and electrophysiological characterization of a neuronal nicotinic receptor using patch-clamp techniques and a preparation of acutely isolated neurons from the $\mathrm{MHb}$. Characterization of nicotinic responses in the CNS by patch-clamp techniques were previously performed on cultured neurons (Aracava et al., 1987; Lipton et al., 1987). At variance with the preparation of cultured neurons, the preparation of acutely isolated neurons as developed by Kay and Wong (1986) offers the opportunity of studying neurons that have developed in vivo their morphological and electrophysiological characteristics. Our experiments were thus performed on small neurons that had retained the morphological characteristics of MHb neurons described in the literaturc (Ramón y Cajal, 1911; Tokunaga and Otani 1978).

In the $\mathrm{MHb}, \mathrm{ACh}$ and nicotine activate channels that appear nonselective for cations as for muscle and ganglionic nicotinic receptors in vertebrates (Adams, 1980; Fenwick et al., 1982). Single-channel experiments performed on the soma of $\mathrm{MHb}$ neurons revealed a single class of $\mathrm{ACh}$-operated channels with an elementary conductance of $26 \mathrm{pS}$ at room temperature. This value differs from those observed for $\mathrm{AChR}$ on rat sympathetic neurons (35 pS, Mathie et al., 1987), rat retinal ganglion cells (40 pS, Lipton et al., 1987), bovine chromaffin cells (44 pS, Fenwick et al., 1982), chick ciliary ganglion (40 pS, Margiotta et al., 1987), and for the 4 different classes of channels found on chick sympathetic ganglionic neurons (Moss et al., 1988). Yet a preliminary report on $\mathrm{PC} 12$ cells mentions the existence of an infrequent $25 \mathrm{pS} \mathrm{ACh}$-activated channel besides the major $40 \mathrm{pS}$ population (Ifune and Steinbach, 1989).

Given that a unique class of single-channel currents with a unitary conductance around $26 \mathrm{pS}$ was observed in all patches tested, we have assumed that $\mathrm{AChR}$ located on $\mathrm{MHb}$ cell bodies or nearby dendrites all belong to the same category of receptors, in order to perform our pharmacological analysis. From a pharmacological point of view, this nicotinic response is characterized by its lack of sensitivity, not only to $\alpha$-bungarotoxin (which 
clearly distinguishes it from muscle $\mathrm{AChR}$ ) but also to neuronal bungarotoxin. This toxin has proved to be a useful probe for studying ganglionic nicotinic receptors in that it blocks nicotinic transmission in chick ciliary ganglion and in rat superior cervical ganglion (see Loring and Zigmond, 1988, for review). It has also recently been shown to block nicotinic effects in rat prefrontal cortex (Vidal and Changeux, 1989) and in retinal ganglion cells (Lipton et al., 1987). The lack of sensitivity of the MHb nicotinic response to neuronal bungarotoxin confirms the existence of distinct types of functional nicotinic receptors in the CNS. On the other hand, the pharmacological profile is unambiguously of the nicotinic type since muscarine and atropine are without effect. Moreover, this AChR is activated by low concentrations of several ganglionic agonists such as DMPP, nicotine, and cytisine, and it is blocked by classical ganglionic nicotinic antagonists such as mecamylamine and hexamethonium, and also by $d$-tubocurarine and dihydro- $\beta$-erythroidine, compounds that are active both in muscle and in ganglions. Finally, our results are consistent with those of McCormick and Prince (1987a) on slices of adult guinea pig MHb who observed a block by hexamethonium but not by $\alpha$-bungarotoxin.

In the $\mathrm{MHb}$ are expressed at least 5 different genes from the rat nicotinic receptor gene family, namely, $\alpha 3, \alpha 4, \beta 2, \beta 3$, and $\beta 4$ (see Lindstrom et al., 1987, for review; Deneris et al., 1988a, b; Wada et al., 1988). Experiments with RNA injection into oocytes have provided evidence that rat $\beta 2$ subunit can, in concert with either $\alpha 2, \alpha 3$, or $\alpha 4$ subunits from rat, produce functional nicotinic receptors with pharmacological properties expected of neuronal nicotinic receptor in that they are all insensitive to $\alpha$-bungarotoxin. Block with neuronal bungarotoxin occurs with $\alpha 3-\beta 2$ and $\alpha 4-\beta 2$ (but not with $\alpha 2-\beta 2$ ). These results suggest that, in the $\mathrm{MHb}$, the $\mathrm{AChR}$ we have characterized do not consist of $\alpha 3-\beta 2$ or $\alpha 4-\beta 2$ subunits. Yet, one must bear in mind that the stoichiometry of neuronal nicotinic receptors is not firmly established (see, however, Whiting et al., 1987) and that posttranslational modifications of neuronal receptors likely differ in an oocyte and in a neuron. Besides, neuronal bungarotoxin did not block the response observed with the combination of an $\alpha 4$ subunit and a non- $\alpha$ subunit from chick (M. Ballivet, personal communication) in a powerful expression system (injection into the oocyte nucleus of cDNAs associated with the promotor of a heat-shock protein). Under these conditions, the elementary conductance of the AChR channels recorded in outside-out patches $\left(20 \mathrm{pS}\right.$ at $\left.20^{\circ} \mathrm{C}\right)$ differed from all channels reported up to now (except for one class of events found in chick sympathetic ganglia; Ballivet et al., 1988; Moss et al., 1988). In conclusion, at this stage, we are not in a position to relate the characteristics of the novel type of nicotinic reccptor found in the MHb to a known set of $\alpha$ and non- $\alpha$ subunits.

In any case, the nicotinic response we have characterized was recorded from the soma or proximal neuritic processes of $\mathrm{MHb}$ cells. This study does not exclude the existence of nicotinic receptors different from those we have characterized that could be located on distal dendrites or on axon terminals. Presynaptic nicotinic receptors, located on the nerve endings of $\mathrm{MHb}$ cells at the extremity of the habenulointerpeduncular tract, have been postulated on the basis of electrophysiological experiments (Brown et al., 1984), a well as immunocytochemical localization (Swanson et al., 1987) and nicotine binding studies (Clarke et al., 1986). Their electrophysiological and pharmacological characteristics are not known, but their existence fits with the fact that a wealth of genes from the AChR family are expressed in the MHb. Future work on the MHb will include an analysis and comparison of the properties of AChRs located near the soma and those located on the nerve terminals, and their assignment to given combinations of subunits.

Finally, we have shown that the nicotinic receptor found on $\mathrm{MHb}$ cells shares, with ganglionic and muscle AChRs, as well as with many different receptor/channel complexes (Adams and Brown, 1975; Role, 1984; Trussel et al., 1988), the property of desensitization. Desensitization of the AChR can be modulated by a variety of effectors, including neuropeptides that coexist with ACh in nerve endings (Role, 1984; Mulle et al., 1988). It will thus be important to test, with a nicotinic synapse, whether desensitization is involved in the regulation of synapse efficacy (Heidmann and Changeux, 1982) in the CNS.

\section{References}

Adams, P. R. (1980) The permeability of end-plate channels to monovalent and divalent metal cations. J. Gen. Physiol. 75: 493-510.

Adams, P. R., and D. A. Brown (1975) Action of $\gamma$-aminobutyric acid on sympathetic ganglion cells. J. Physiol. (Lond.) 250: 85-120.

Aracava, Y., S. Deshpande, K. Swanson, A. Rapoport, S. Wonnacott, G. Lunt, and E. Albuquerque (1987) Nicotinic acetylcholine receptors in cultured neurons from the hippocampus and brain stem of the rat characterized by single channel recording. FEBS Lett. 222: 63-70.

Ballivet, M., P. Nef, S. Couturier, D. Rungger, C. R. Bader, D. Bertrand, and E. Cooper (1988) Electrophysiology of a chick neuronal nicotinic ACh receptor expressed in Xenopus oocytes after cDNA injection. Neuron 1: 847-852.

Boulter, J., K. Evans, D. Goldman, D. Martin, D. Treco, S. Heinemann, and J. Patrick (1986) Isolation of a cDNA clone coding for a possible neural nicotinic acetylcholine receptor $\alpha$-subunit. Nature 319: 368374.

Bradley, P. B., and A. Dray (1972) Short latency excitation of brain stem neurones in the rat by acetylcholine. Br. J. Pharmacol. 4: 372374.

Brown, D. A., R. J. Docherty, and J. V. Halliwell (1984) The action of cholinomimetic substances on impulse conduction in the habenulointerpeduncular pathway of the rat in vitro. J. Physiol. (Lond.) 353: 101-109.

Chiappinelli, V. A. (1983) Kappa toxin: A probe for neuronal nicotinic receptor in the avian ciliary ganglion. Brain Res. 277: 9-21.

Clarke, P., D. W. Hommer, A. Pert, and L. R. Skirboll (1985a) Electrophysiological actions of nicotine on substantia nigra single units. Br. J. Pharmacol. 8: 827-835.

Clarke, P., R. D. Schwartz, S. M. Paul, C. B. Pert, and A. Pert (1985b) Nicotinic binding in rat brain: Autoradiographic comparison of $\left[{ }^{3} \mathrm{H}\right] \mathrm{ACh},\left[{ }^{3} \mathrm{H}\right]$ nicotine, and $\left[{ }^{125} \mathrm{I}\right] \alpha$-bungarotoxin. J. Neurosci. 5: $1307-$ 1313.

Clarke, P., G. Hamill, N. Nadi, D. Jacobowitz, and A. Pert (1986) $\left[{ }^{3} \mathrm{H}\right]$-Nicotine and $\left[{ }^{125} \mathrm{I}\right] \alpha$-bungarotoxin-labeled nicotinic receptors in the interpeduncular nucleus of rats. Effects of habenular differentiation. J. Comp. Neurol. 251: 407-413.

Contestabile, A., and L. Villani (1983) The use of kainic acid for tracing neuroanatomical connections in the septohabenulointerpeduncular system of the rat. J. Comp. Neurol. 214: 459-469.

Curtis, D. R., and R. W. Ryall (1966) The synaptic excitation of Renshaw cells. Exp. Brain Res. 2: 81-96.

Deneris, E. S., J. Connolly, J. Boulter, E. Wada, K. Wada, L. W. Swanson, J. Patrick, and S. Heinemann (1988a) Primary structure and expression of $\beta 2$ : A novel subunit of neuronal nicotinic acetylcholine receptors. Neuron 1: 45-54.

Deneris, E. S., J. Boulter, J. Patrick, and S. Heinemann (1988b) Identification of a cDNA encoding a new subunit of neuronal acetylcholine receptors. Soc. Neurosci. Abstr. 14:95.11.

Deutch, A. Y., J. Holliday, H. R. Roth, L. L. Y. Chun, and E. Hawrot (1987) Immunocytochemical localization of a neuronal acetylcholine receptor in mammalian brain. Proc. Natl. Acad. Sci. USA 84: 8697 8701.

Duggan, A. W., J. G. Hall, and C. Y. Lee (1976) $\alpha$-Bungarotoxin, cobra neurotoxin, and excitation of Renshaw cells by acetylcholine. Brain Res. 107: 166-170. 
Egan, T., and R. A. North (1986) Actions of ACh and nicotine on rat coeruleus neurons in vitro. Neuroscience 19:565-571.

Fenwick, E. M., A. Marty, and E. Neher (1982) A patch-clamp study of bovine chromaffin cells and their sensitivity to ACh. J. Physiol. (Lond.) 331: 577-597.

Garza, R. De la, T. J. McGuire, R. Freedman, and B. J. Hoffer (1987) Selective antagonism of nicotine actions in the rat cerebellum with $\alpha$-bungarotoxin. Neuroscience 23: 887-891.

Goldman, D., D. Simmons, L. W. Swanson, J. Patrick, and S. Heinemann (1986) Mapping of brain areas expressing RNA homologous to two different acetylcholine receptors $\alpha$-subunit cDNAs. Proc. Natl. Acad. Sci. USA 83: 4076-4080.

Goldman, D., E. Deneris, W. Luyten, A. Kochhar, J. Patrick, and S. Heinemann (1987) Members of a nicotinic acetylcholine receptor gene family are expressed in different regions of the mammalian central nervous system. Cell 48: 965-973.

Gottesfeld, Z., and D. M. Jacobowitz (1979) Cholinergic projections from the septal-diagonal band area to the habenular nuclei. Brain Res. 176: $291-394$.

Gustafsson, B., M. Galvan, P. Grafe, and H. Wigström (1982) Transient outward current in a mammalian central neurone blocked by 4-aminopyridine. Nature 299: 252-254.

Hamill, O. P., A. Marty, E. Neher, B. Sakmann, and F. J. Sigworth (1981) Improved patch-clamp techniques for high resolution current recording from cells and cell-free membrane patches. Pfluegers Arch. 391: $85-100$

Heidmann, T., and J. P. Changeux (1982) Un modèle moléculaire de régulation d'efficacité d'une synapse chimique au niveau postsynaptique. C.R. Acad. Sci. Paris 294: 121-123.

Herkenham, M., and W. J. H. Nauta (1979) Efferent connections of the habenular nuclei in the rat. J. Comp. Neurol. 187: 19-48.

Ifune, C. K., and J. H. Steinbach (1989) Functional characteristics of nicotinic ACh receptors on PC12 cells. Biophys. J. 55: 552a.

Kay, A. R., and Wong, R. K. S. (1986) Isolation of neurons suitable for patch-clamping from adult mammalian central nervous system. J. Neurosci. Methods 16: 227-238.

Lindstrom, J., R. Schoepfer, and P. Whiting (1987) Molecular studies of the neuronal nicotinic acetylcholine receptor family. Mol. Neurobiol. 1: 281-337.

Lipton, S. A., E. Aizenman, and R. Loring (1987) Neural nicotinic responses in solitary mammalian retinal ganglion cells. Pfluegers Arch. 410: 37-43.

London, E. D., S. B. Waller, and J. K. Wamsley (1985) Autoradiographic localization of $\left[{ }^{3} \mathrm{H}\right]$ nicotine binding sites in rat brain. Neurosci. Lett. 53: 179-184.

London, E. D., R. J. Connolly, M. Szikszay, J. K. Wamsley, and M. Dam (1988) Effects of nicotine on local cerebral glucose utilization in the rat. J. Neurosci. 8: 3920-3928.

Loring, R. H., and R. E. Zigmond (1988) Characterization of neuronal nicotinic receptors by snake venom neurotoxins. Trends Neurosci. 11: 73-78.

Loring, R. H., V. A. Chiappinelli, R. E. Zigmond, and J. B. Cohen (1984) Characterization of a snake venom neurotoxin which blocks nicotinic transmission in the avian ciliary ganglion. Neuroscience 11:989-999.

Margiotta, J. F., D. K. Berg, and J. E. Dionne (1987) The properties and regulation of functional acetylcholine receptors on chick ciliary ganglion neurons. J. Neurosci. 7: 3612-3622.
Mathie, A., S. G. Cull-Candy, and D. Colqhoun (1987) Single-channel and whole-cell currents evoked by $\mathrm{ACh}$ in dissociated sympathetic neurons of the rat. Proc. R. Soc. Lond. (Biol.) 232: 239-248.

McCormick, D. A., and D. A. Prince (1987a) Acetylcholine causes rapid nicotinic excitation in the medial habenular nucleus of guinea pig in vitro. J. Neurosci. 7: 742-752.

McCormick, D. A., and D. A. Prince (1987b) Actions of acetylcholine in the guinea-pig and cat medial and lateral geniculate nuclei, in vitro. J. Physiol. (Lond.) 392: 147-165.

Miller, J. D., D. M. Murakami, and C. A. Fuller (1987) The response of suprachiasmatic neurons of the rat hypothalamus to photic and nicotinic stimuli. J. Neurosci. 7: 978-986.

Moss, B. L., S. M. Schuetze, and L. W. Role (1988) Functional properties and developmental regulation of nicotinic acetylcholine receptors in chick sympathetic neurons. Soc. Neurosci. Abstr. 14: 260.1.

Mulle, C., P. Benoit, C. Pinset, M. Roa, and J. P. Changeux (1988) Calcitonin gene-related peptide enhances the rate of desensitization the nicotinic acetylcholine receptor in cultured mouse muscle cells. Proc. Natl. Acad. Sci. USA 85: 5728-5732.

Nef, P., C. Oneyser, C. Alliod, S. Couturier, and M. Ballivet (1988) Genes expressed in the brain define three distinct neuronal nicotinic acetylcholine receptors. EMBO J. 7: 595-601.

Ramón y Cajal, S. (1911) Histologie du système nerveux de l'homme et des vertébrés, Maloine, Paris.

Ravdin, P. M., and D. K. Berg (1979) Inhibition of neuronal acetylcholine sensitivity by a toxin from Bungarus multicinctus venom. Proc. Natl. Acad. Sci. USA 75: 2072-2076.

Role, L. W. 1984 Substance P modulation of acetylcholine-induced currents in embryonic chicken sympathetic and ciliary ganglion neurons. Proc. Natl. Acad. Sci. USA 81: 2924-2928.

Stelzer, A., A. R. Kay, and R. K. S. Wong (1988) GABA-receptor function in hippocampal cells is maintained by phosphorylation factors. Science 241: 339-341.

Swanson, L., D. Simmons, P. Whiting, and J. Lindstrom (1987) Immunohistochemical localization of neuronal nicotinic receptors in the rodent central nervous system. J. Neurosci. 7: 3334-3342.

Tokunaga, A., and K. Otani (1978) Fine structure of the medial habenular nucleus in the rat. Brain Res. 150: 600-606.

Trussel, L. O., L. L. Thio, C. F. Zorumski, and G. D. Fischbach (1988) Rapid desensitization of glutamate receptors in vertebrate central neurons. Proc. Natl. Acad. Sci. USA 85: 2834-2838.

Vidal, C., and J. P. Changeux (1989) Pharmacological profile of nicotinic acetylcholine receptors in the rat prefrontal cortex: An electrophysiological study in a slice preparation. Neuroscience 29:261-270.

Wada, K., M. Ballivet, J. Boulter, J. Connolly, E. Wada, E. Deneris, L. Swanson, S. Heinemann, and J. Patrick (1988) Functional expression of a new pharmacological subtype of hrain nicotinic ACh receptor. Science $240: 330-334$.

Whiting, P. J., L. Rushya, J. M. Barbara, and J. M. Lindstrom (1987) Structurally different neuronal nicotinic acetylcholine receptor subtypes purified and characterized using monoclonal antibodies. J. Neurosci. 7: 4005-4016.

Williams, H., and J. L. Robinson (1984) Binding of the nicotinic cholinergic antagonist, dihydro- $\beta$-erythroidine, to rat brain tissue. J. Neurosci. 4: 2906-2911. 